\title{
Lupinus - a note on site formation in action
}

\author{
M.L. Schwede \\ 28 Bedford Street, Nedlands Western Australia 6009, Australia. \\ Email: scampy@iinet.net.au
}

\begin{abstract}
Hallam proposed a four phase chronological sequence to interpret the surface artefact scatters which is the main archaeological site type on the Swan Coastal Plain. The presence of Lupinus seeds and size sorting in the artefact assemblage from excavations at the Bennett Brook site suggested disturbance had resulted from agricultural activity since European settlement. Without the presence of the seeds the disturbance would not have been detected, indicating that more attention should be paid to site formation processes in interpreting and assessing sites in the Perth area.
\end{abstract}

KEYWORDS: disturbance, surface artefact scatters, Swan Coastal Plain, quartz

\section{INTRODUCTION}

Surface scatters comprise the main archaeological site type recorded on the Swan Coastal Plain. The presence or absence of a specific rock type known as bryozoan cryptocrystalline chert is used as a broad indicator of a date range for the deposition of artefactual material. Research has indicated that the sources of this chert lie directly west of the Swan Coastal Plain off the coast and were submerged to its present depth about 6,500 BP (Glover 1975a, 1975b, 1984). Sylvia Hallam's Swan Area Archaeological Survey (1986) which was completed in 1986 documented 396 sites in the Swan Coastal Plain. From her surveys and collections she proposed a four phase chronological sequence which still forms the basis for the interpretation of archaeological sites in the region. This paper presents a case study from an excavation at one of the sites originally recorded by Hallam's project that raises some questions about processes of site formation and thus the long accepted chronological sequence for the Swan Coastal Plain. The research for this paper, the fieldwork, data collection and analysis were all carried out over 20 years ago in 1983. Although this imposes a set of methodological and theoretical limitations on the data presented here, the central observations from that excavation are still relevant and importantly provide some questions that the next generation of Western Australian archaeologists might like to pursue.

Our knowledge of the archaeology of the Swan Coastal Plain has increased over the past 30 years, often raising more questions than answering them. Research that has been undertaken in the region has contributed to information concerning resource usage and movement of early populations. However, one aspect that has been largely neglected is the processes of site formation and their effect on our interpretation and understanding of both surface scatters and excavations. This is further complicated by the fact that the Swan Coastal Plain itself has been disturbed by both urban and rural development over the past 150 years since colonisation. Thus, problems of interpretation of sites can arise where areas have been subject to disturbance because of natural phenomena or human agencies. The Bennett Brook site, DIA Site 3997, is one such example where post-contact material remains in the form of lupin seeds were found in sediments along with what are interpreted to be late Holocene or pre-contact stone artefacts.

\section{THE ARCHAEOLOGY OFTHE SWAN COASTAL PLAIN}

In the early 1970s, Hallam (1972) proposed a four phase system to classify 143 surface sites she had located on the Swan Coastal Plain.

- $\quad$ Early - characterised by the presence of bryozoan chert and attributed to the period before 6,500 BP;

- $\quad$ Middle - characterised by the presence of backed pieces, utilised over the last 4,000 years;

- $\quad$ Late - characterised by the presence of a high percentage of amorphous quartz pieces; and,

- $\quad$ Final - characterised by the presence of post-contact material, especially glass, (Hallam 1981). 
Hallam's collections were obtained from the sand plain and alluvial terraces bordering the Darling Scarp. Other archaeological investigations in the metropolitan area have primarily been archaeological surveys undertaken by contract archaeologists, who have also used the four phase system proposed by Hallam.

Hallam tentatively dated these surface sites on the basis of her excavations at Orchestra Shell and Frieze Caves and on the lithological content of surface assemblages. It was not until Pearce's $(1977,1978)$ excavations at Walyunga, an open dune site located in the foothills of the Darling Scarp north-east of Perth, that a firm sequence with dates could be developed, incorporating the appearance of backed tools and the use of bryozoan chert. Pearce's analysis provided broad confirmation for the four phase system and linked it to an absolute timescale. The geological research undertaken by Glover (1975a, 1975b, 1976) during this period on sources of lithic material, especially bryozoan chert, also supported Hallam's phases to some degree. Thus, interpretation of surface scatters and excavations in south-west Western Australia has primarily depended on the absence or presence of this Eocene material, bryozoan cryptocrystalline chert. The presence/absence of types and European material has also been used as a time indicator in interpreting assemblages.

Schwede (1990) was critical of the four phase system in her study of quartz-dominated assemblages and demonstrated that bryozoan chert could not be used alone to date otherwise undatable artefact assemblages, especially surface assemblages. Furthermore, she found that changes in flake size and shape were more indicative of variations in assemblages attributable to a range of factors including the natural environment, availability of stone, sampling techniques and misuse of terminology rather than chronology. Similar results have been noted in more recent Australia studies by Hiscock $(2001,2002)$ and Hiscock and Allen (2000), in which it was found that the presence/absence of artefact types, specifically backed blades, depended on sample size and the recognition of processes that can affect samples such as weathering and fragmentation.

The assemblage from the excavations at Bennett Brook (DIA Site 3997) fitted into Hallam's phase system. This could be interpreted as a Late phase assemblage on the basis of the high percentage of quartz pieces from both the surface collection and excavations and absence of backed pieces, bryozoan chert and post-contact material. However, the presence of lupin seeds in the excavation associated with artefactual material suggested that the four phase chronological scheme pays insufficient attention to site formation processes.

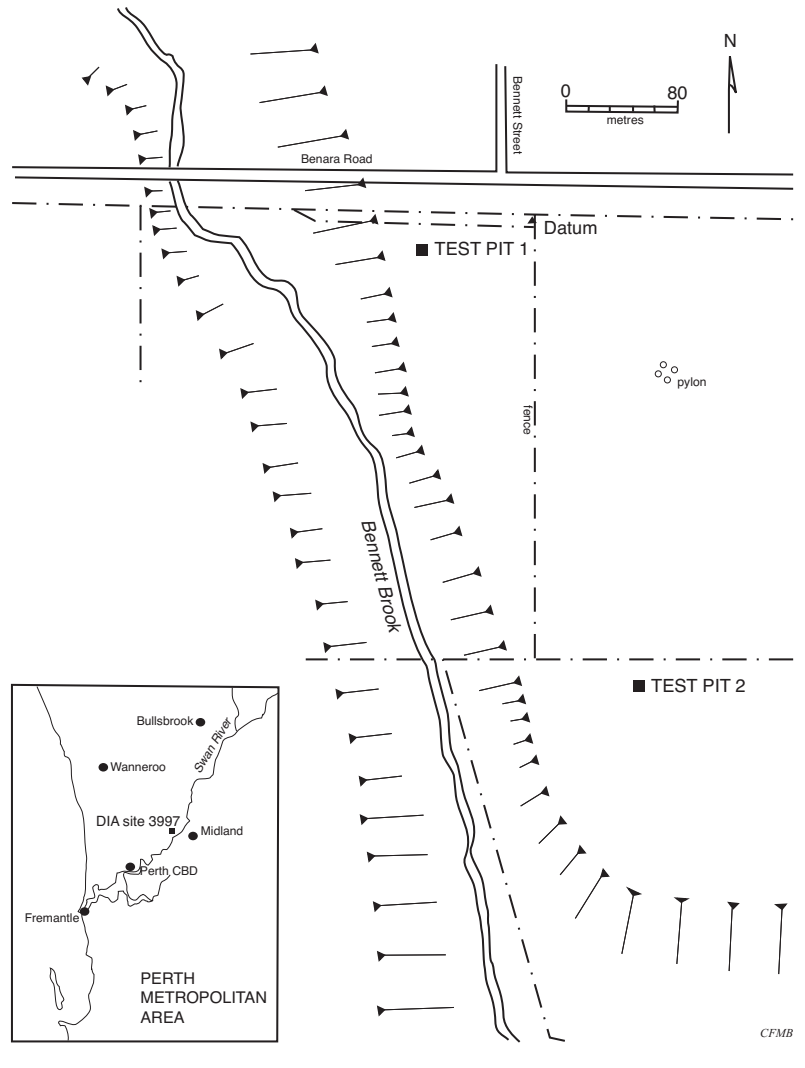

FIGURE 1 Location of test pits at the Bennett Brook site (DIA 3997).

\section{DIA SITE 3997 - BENNETT BROOK}

During an archaeological survey conducted on gas pipeline laterals for the East Perth Metropolitan area, it was recommended that test pits be excavated in the Caversham/Lockridge area, near to where Bennett Brook crosses Benara Road (Schwede 1983, 1984). DIA 3997 (401689mE $6472649 \mathrm{mN}$, Zone 50) was located on the eastern side of Bennett Brook, covering an area of approximately $250 \times 250 \mathrm{~m}$ over ploughed paddocks used primarily for grazing horses and cattle (Figure 1). The site had originally been recorded in 1976 as part of Hallam's Swan Coastal Plain survey, and at that time a small surface collection consisting entirely of quartz was taken from ploughed areas.

The Bennett Brook site is located on the siliceous grey sands of the Bassendean Dune System, which overlie the alluvial soils of the Pinjarra Plain to the east (McArthur and Bettenay 1974). The area has played a significant part in the history of early European settlement as well as being equally important to the Aboriginal people. Historically the area was one of the first in Western Australia to be settled by Europeans. With the establishment of the Swan River Colony in 1829, property blocks had been distributed to early colonists on the Swan Coastal Plain. Those property blocks bordering the 
Swan River to the east were long and narrow with small river frontages. The township of Guildford, a few kilometres to the south, was also established during the same year. Within a kilometre radius of where the test pits were excavated, the area still offers a dependable water supply, in the form of the brook itself and a fresh water spring. While little of the original vegetation remains, traces of open woodland can still be seen, consisting of Eucalyptus calophylla, E. marginata, Banksia spp. as well as E. rudis, Melaleuca rhaphiophylla, rushes and grasses along the creek edges (Heddle et al. 1978). The area still attracts abundant birdlife, waterfowl and other aquatic wild life. Today this area is covered by residential development with heavy industrialisation and urbanisation as well as wineries existing on the fringes. One of the last Aboriginal fringe dwellers' camps in the metropolitan area used to be located to the south of the site.

\section{EXCAVATIONS}

Two days were spent in the field excavating two $2 \times 1 \mathrm{~m}$ test pits located $221 \mathrm{~m}$ apart. They were excavated in $10 \mathrm{~cm}$ spits and stepped at a depth of approximately $50 \mathrm{~cm}$ to $1 \times 1 \mathrm{~m}$ squares, and again at $80 \mathrm{~cm}$ to $1 \times 0.5 \mathrm{~m}$ squares to contain potential cave-ins of sand. Test Pit 1 was excavated to a depth of $145 \mathrm{~cm}$, with the last $50 \mathrm{~cm}$ containing no cultural material; Test Pit 2 was dug to a depth of $100 \mathrm{~cm}$ and had to be refilled at the end of the day to ensure stock occupying the paddock would not fall in. Soil conditions were the same for both test pits, with grey sandy soil intermixed with dead wild oat grass near the surface, becoming more compact, damp and stained. Beginning at about 15$25 \mathrm{~cm}$ there was a definite colour change to yellow sand (Table 1). Clear plough marks were discernable in the stratigraphy of Test Pit 1 , which extended to a depth of $30 \mathrm{~cm}$. In addition to soil samples, carbon samples were collected (considered to be carbonised rootlets), and seeds were also noted.

A sparse collection of flaked material was excavated from both test pits, reflecting the sparse surface scatter over the $250 \mathrm{~m}^{2}$ area. A total of 83 artefacts was collected from Test Pit 1, with 94\% consisting of utilised or non-utilised quartz, and the remainder being non-utilised pieces of mylonite and silcrete (Table 2). Out of the 184 artefacts collected from Test Pit 2, 97\% were quartz (Table 3).

At first glance, the composition, sample size and typological characteristics of flakeable material from both test pits appears to be similar to surface scatters recorded throughout the metropolitan area. However Lupinus seeds were present in every spit of both pits to a depth of $100 \mathrm{~cm}$. Unfortunately, the quantity of seeds per spit was not recorded in the field. Some evidence of size sorting was also apparent in the assemblage.

\section{LUPINUS}

The history of Lupinus, commonly known as lupins, is well known archaeologically and historically in the Old World. Its cultivation was well established in early Greece and Rome, and it was probably harvested as early as 2,000 BC in Egypt (Gladstones 1970: 123). In Australia, however, it is a recent arrival, where its main importance is to farmers for fodder and green manure. It is also a garden plant. Accounts in newspapers suggest the seeds were introduced into Western Australia as early as the 1860s, the seeds being ground into flour by convicts (Gladstones 1958: 237). The exact date of their introduction into the Caversham/Lockridge

TABLE 1 Test Pits 1 and 2, DIA 3997: relationship between spits and stratigraphy.

TEST PIT 1

\begin{tabular}{|c|c|c|c|}
\hline LAYER & $\begin{array}{l}\text { SPIT } \\
\text { NUMBER }\end{array}$ & LAYER & $\begin{array}{l}\text { SPIT } \\
\text { NUMBER }\end{array}$ \\
\hline $\begin{array}{l}\text { Humic zone } \\
\text { (black sandy soil) } 0-15 \mathrm{~cm}\end{array}$ & 1 & $\begin{array}{l}\text { Humic zone } \\
\text { (black sandy soil) 0-10 cm }\end{array}$ & 1 \\
\hline $\begin{array}{l}\text { Plough zone } \\
\text { (black/yellow soil) } 15-35 \mathrm{~cm}\end{array}$ & $2-3$ & $\begin{array}{l}\text { Plough zone } \\
\text { (black/yellow soil) } 10-30 \mathrm{~cm}\end{array}$ & $2-3$ \\
\hline $\begin{array}{l}\text { Yellow sandy soil } \\
35-145 \mathrm{~cm}\end{array}$ & $4-10$ & $\begin{array}{l}\text { Yellow sandy soil } \\
30-100 \mathrm{~cm}\end{array}$ & $4-10$ \\
\hline
\end{tabular}

TEST PIT 2 


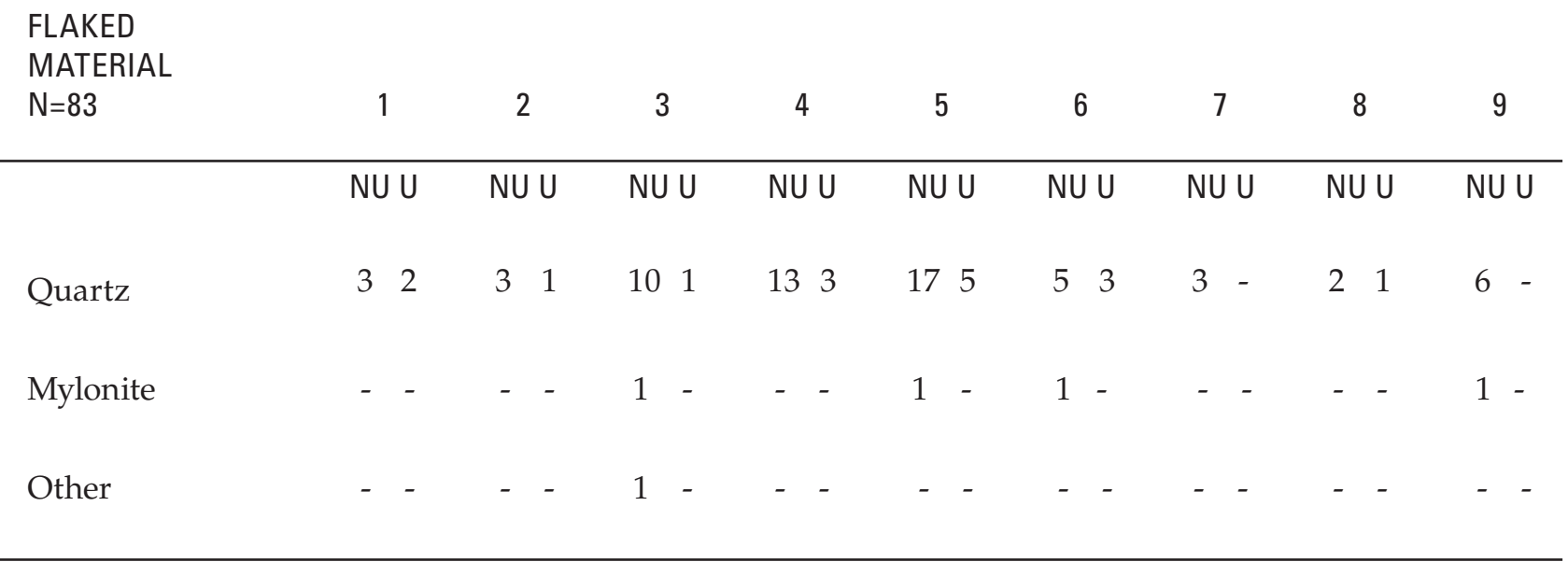

area is unknown; however, Gladstones (1958) describes reports of lupins being widespread by the 1890s in the area under consideration; their use was ornamental rather than for agricultural purposes.

The seeds excavated from the two test pits to a depth of $1 \mathrm{~m}$ belong to Lupinus angustifolius, the bitter wild blue lupin commonly seen along roadsides and open fields through the metropolitan area. The seed coat is hard, variously patterned and coloured, ranging in size from 4-6 $\times 3-5 \times$ 3-4 mm (Gladstones 1969, 1974). Seeds collected in soil samples from the pits ranged in weight from $0.046-0.150 \mathrm{~g}$. The incorporation of these seeds in the sediments could result from a range of factors including surface compaction, erosion, the activity of rabbits, rodents or other burrowing animals, insects, or even worm activity; their food value to insects or animals is doubtful because of the bitterness and alkaloid toxicity of the wild lupin variety (Gladstones 1970; Pate, pers. comm.).

\section{ANALYSIS OF FLAKED MATERIAL}

Flaked stone was classified by raw material (quartz, mylonite and other) into categories of nonutilised stone material (such as fragments, flakes or cores) or utilised/retouched (edge damaged) pieces. The latter were all manufactured from quartz and included an adze slug, a bipolar piece and other edge damaged pieces. The classification and analysis of assemblages from the Swan Coastal Plain used here follows Schwede (1990). There was no discernable change in artefact typology within and between each pit.

Surface area was used as the primary measure of size. Most flakeable material collected from both test pits was less than $15 \mathrm{~mm}^{2}$. For Test Pit 1 it was $98 \%$ and for Test Pit 2 it was 95\%. Table 4 indicates that artefact size decreased through spits 1 to 8 , or the first $75 \mathrm{~cm}$ of deposit. Only 8 artefacts were collected from the remaining $25 \mathrm{~cm}$ of deposit. All

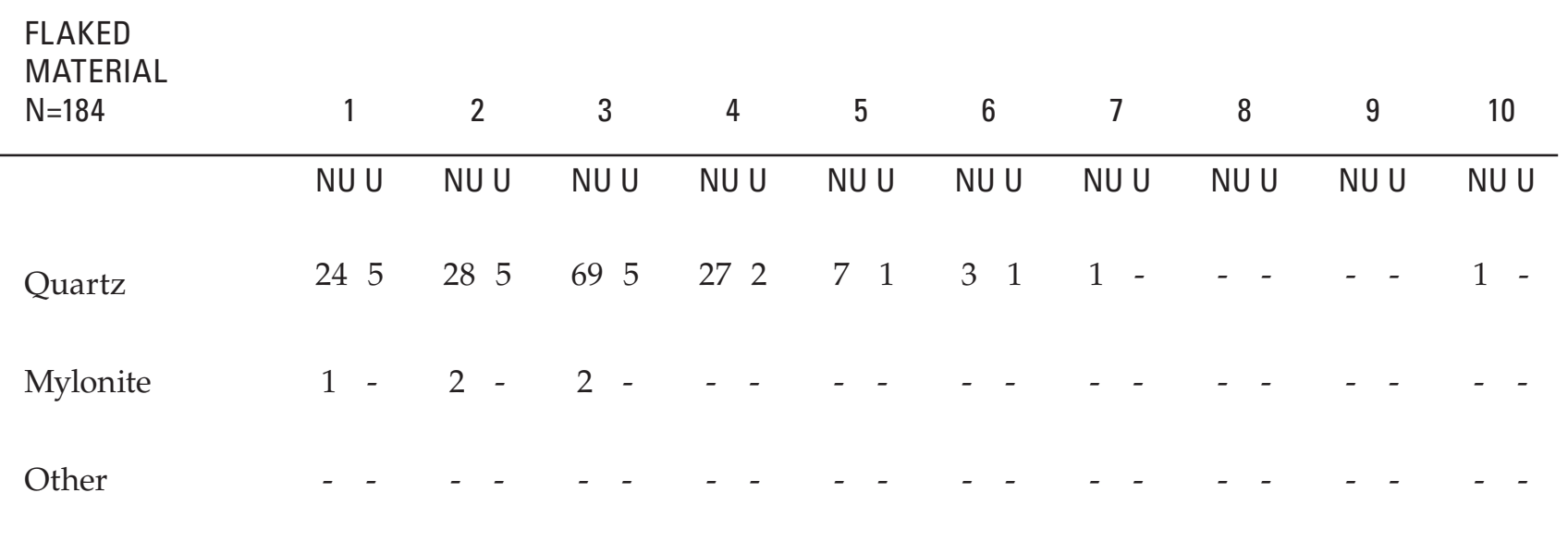


TABLE $4 \quad$ Test Pits 1 and 2, Spits 1 to 10, DIA 3997: distribution of artefacts by size classes and depth.

\begin{tabular}{lllllllllllllllllll} 
SPIT NUMBER & 1 & 2 & 3 & 4 & 5 & 6 & 7 & 8 & 9 & 10 \\
\hline TEST PITS & 12 & 12 & 12 & 12 & 12 & 12 & 12 & 12 & 12 & 12
\end{tabular}

\section{ARTEFACT SIZE}

\begin{tabular}{lllllllllllllllll}
$<5 \mathrm{~mm}^{2}$ & 3 & 10 & 2 & 3 & 4 & 22 & 7 & 14 & 9 & 1 & 3 & 3 & - & $1-$ & $2-$ & - \\
$<10 \mathrm{~mm}^{2}$ & 1 & 16 & 1 & 24 & 8 & 43 & 5 & 13 & 10 & 6 & 5 & 1 & 31 & - & $5-$ & - \\
$<15 \mathrm{~mm}^{2}$ & 1 & 3 & 1 & 3 & - & 8 & 4 & 1 & 4 & 1 & $1-$ & - & $1-$ & - & - \\
$<20 \mathrm{~mm}^{2}$ & - & 1 & - & 5 & 1 & 2 & - & 1 & - & - & - & - & $1-$ & - & - \\
$<25 \mathrm{~mm}^{2}$ & - & - & - & - & -1 & - & - & - & - & - & - & - & - \\
\hline TOTAL & 5 & 30 & 4 & 35 & 1376 & 1629 & 238 & 94 & 31 & $3-$ & $7-$ & -1 \\
ARTEFACTS & & & & & & & & & &
\end{tabular}

but one were less than $15 \mathrm{~mm}^{2}$, but sample size is considered too small for reliable interpretation. More than half the artefacts were smaller in size than those lupin seeds recorded.

Figure 2 shows the overall distribution of artefacts in each pit per cubic metre. In Test Pit 1 most artefacts (23) were found around $40-50 \mathrm{~cm}$, while Test Pit 2 (76) peaks around $20-30 \mathrm{~cm}$. This concentration of artefacts broadly corresponds to the base of the ploughsoil in both pits.

Figure 3 shows the distribution of artefacts by weight per $\mathrm{m}^{3}$. The pattern is broadly similar to Figure 2 for each pit. It should be noted that over $50 \%$ of all individually weighed artefacts were less than the average weight of lupin seeds collected.

\section{DISCUSSION}

Studies in site formation processes are not rare in Australia, though few have been undertaken

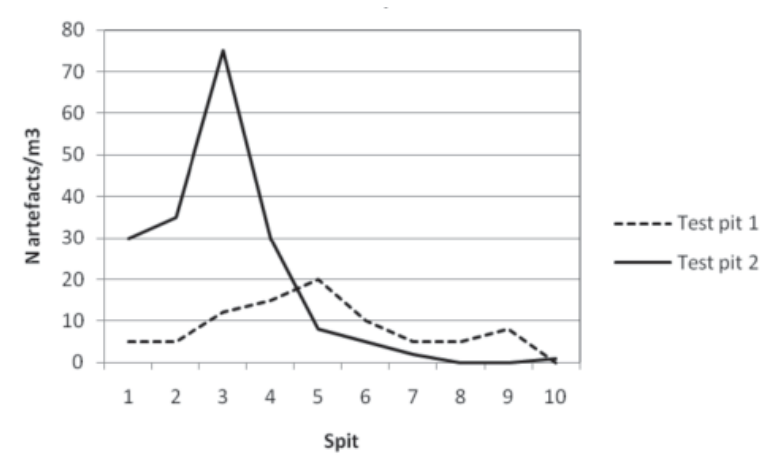

FIGURE 2 Artefact density. Number of artefacts per $\mathrm{m}^{3}$, Test Pits 1 and 2, Spits 1 to 10 . in Western Australia. Examples include artefact displacement studies undertaken by Stockton (1973) for rock shelters, Hughes and Lampert (1977) for shell midden deposits as well as Hiscock's (1983) spatial analysis of the Surface Slope Site. Many studies have been undertaken in the United States and other parts of the world, investigating disturbance processes, impact studies and so forth on archaeological sites (e.g. Schiffer 1983, 1987).

It is well known that a wide range of processes can cause alteration and displacement of artefacts within sites both horizontally and vertically (Stockton 1973; Hiscock 1985; Schiffer 1987). Stockton (1973) showed that even a short trampling experiment could displace small objects as much as $16 \mathrm{~cm}$. Richardson's (1992) conjoin analysis of the Kenniff Cave assemblage showed substantial vertical displacement of artefacts had occurred in a site which appeared to have a high degree of stratigraphic integrity. Artefacts can move up and

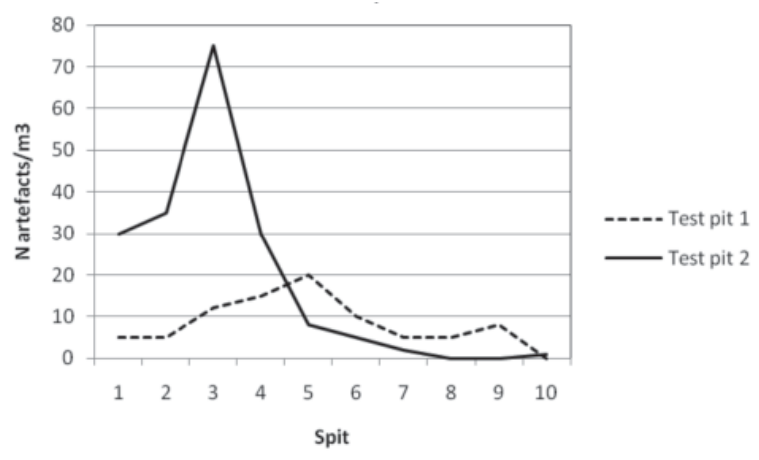

FIGURE 3

Artefact density. Weight $(\mathrm{g})$ of artefacts per $\mathrm{m}^{3}$, Test Pits 1 and 2, Spits 1 to 10 . 
down soil profiles through mechanical processes such as trampling and ploughing. Size sorting is a common result of both trampling and ploughing. Experiments in these processes have shown that small objects tend to be displaced downwards and large objects tend to come to the surface (Schiffer 1987: 126-132). Natural processes that can result in the movement of artefacts include burrowing animals, earthworms and tree roots. The nature of the sediments, or penetrability, influences the movement of artefacts. Thus, artefacts are likely to be particularly mobile in loose sandy deposits like the Bassendean Sands.

Because of the type and size of material found (primarily quartz) and because there was no utilised European material, archaeological interpretation suggests that the Bennett Brook site was probably utilised within the last 4,000 years, but prior to colonisation. However, the evidence of the vertical displacement of lupin seeds, which are highly comparable in size to the artefacts, implies that there has been substantial movement of material within the deposits. The most likely cause of this is the agricultural activity that has occurred since European settlement. It should be noted that without the presence of lupin seeds the Bennett Brook site would have appeared to be undisturbed. This suggests that apparently stratified sites in the Swan Coastal Plain, particularly those on the Bassendean Sands, should be interpreted with considerable caution.

\section{CONCLUSION}

The observations from the Bennett Brook excavations are still relevant to the interpretation of surface scatters on the Swan Coastal Plain. It is acknowledged that there are inherent problems in the assessment of artefact scatters on sandy soils due to the limitations presented by site formation processes. These are equally applicable to test excavations that have been undertaken in similar soils, as illustrated here. While Hallam's four phase sequence has been valuable in assessing surface sites, new approaches are now required. In light of these issues Bowdler et al. (1991) proposed that new research questions and methods were needed to be developed to understand and interpret previous and future archaeological research on the Swan Coastal Plain. The spatial approach proposed by Holdaway et al. (1998) in investigating the distribution of artefacts across the landscape in New South Wales is a possible avenue of enquiry, which in turn could assist in the interpretation and management of artefacts. A comparable project has recently been developed on the Swan Coastal Plain to understand and manage Aboriginal heritage values of the Brookdale redevelopment area (Tempus Archaeology 2006). Both of these investigations address new ways of researching as well as assessing and managing surface scatters across various landscapes.

Further investigation of site formation processes in the Swan Coastal Plain should assist in developing a firmer chronological framework for the region as well as assisting in significance assessment of sites in the Perth Metropolitan area. As Schiffer (1983: 675) stated '... Unless the genesis of deposits is understood, one cannot infer the behaviours of interest from artefact patterns in those deposits.'

\section{REFERENCES}

Bowdler, S. Strawbridge, L. and Schwede, M. (1991). Archaeological mitigation in the Perth metropolitan region. Australian Archaeology 32: 21-25.

Gladstones, J.S. (1958). Study of the genetics and agronomy of the genus Lupinus with particular reference to varieties of potential value in Western Australia. PhD Thesis, University of Western Australia: Nedlands.

Gladstones, J.S. (1969). Lupins in Western Australia. 1. Species; and varieties. Journal of Agriculture, Western Australia 10: 318-324.

Gladstones, J.S. (1970). Lupins as crop plants. Field Crop Abstracts 23: 124-148.

Gladstones, J.S. (1974). Lupins of the Mediterranean region and Africa. Western Australian Department of Agriculture, Technical Bulletin No 26.

Glover, J.E. (1975a). Aboriginal chert artefacts probably from quarries on the continental shelf, Western Australia. Search 6: 392-394.

Glover, J.E. (1975b). The petrology and probable stratigraphic significance of Aboriginal artefacts from part of south-western Australia. Journal of the Royal Society of Western Australia 58: 75-85.

Glover, J.E. (1976). The petrology and archaeological significance of mylonite rocks in the Precambrian shield near Perth, Western Australia. Journal of the Royal Society of Western Australia 59: 33-37.

Glover, J.E. (1984). Geochemistry and provenance of Eocene chert artefacts, southwestern Australia. Archaeology in Oceania 19: 16-20.

Hallam, S.J. (1972). An archaeological survey of the Perth area, Western Australia: a progress report on art and artefacts, dates and demography. Australian Institute of Aboriginal Studies Newsletter 3: 11-19.

Hallam, S.J. (1981). Application to Australian Research Grants Committee for 1982. Unpublished MS.

Hallam, S.J. (1986). Prehistoric Aboriginal populations on the Swan Coastal Plain, Western Australia. Unpublished report to Australian Research Grants Scheme.

Heddle, E.M., Lonergan, O.W. and Havel, J.J. (1978). Perth Sheet - Vegetation, WA Map III. Department of Conservation and Environment: Perth.

Hiscock, P. (1983). Appendix 3. The Slope Site: spatial analysis of a surface site in the Five Forests. In: Byrne, D., The Five Forests: an archaeological and an anthropological investigation. National Parks and Wildlife Service of New South Wales: Sydney.

Hiscock, P. (1985). The need for a taphonomic perspective 
in stone artefact analysis. Queensland Archaeological Research 2: 82-97.

Hiscock, P. (2001). Sizing up prehistory: sample size and composition of artefact assemblages. Australian Aboriginal Studies 2001/1: 48-62.

Hiscock, P. (2002). Quantifying the size of artefact assemblages. Journal of Archaeological Science 29: 251-258.

Hiscock, P. and Allen, H. (2000). Assemblage variability in the Willandra Lakes. Archaeology in Oceania 35: 97-103.

Hughes, P.J. and Lampert, R.F. (1977). Occupational disturbance and types of archaeological deposit. Journal of Archaeological Science 4: 135-140.

Holdaway, S., Witter, D., Fanning, P., Musgrave, R., Cochrane, G., Doelman, T., Greenwood, S., Pigdon, D. and Reeves, J. (1998). New approaches to open site spatial archaeology in Sturt National Park, New South Wales, Australia. Archaeology in Oceania 33: 1-19.

McArthur, W.M. and Bettenay, E. (1974). The development and distribution of the soils of the Swan Coastal Plain, Western Australia. CSIRO Soils Publication 16.

Pearce, R.H. (1977). Relationship of chert artefacts at Walyunga in southwest Australia, to Holocene sea Levels. Search 10: 375-377.

Pearce, R.H. (1978). Changes in artefact assemblages during the last 8000 years at Walyunga, Western Australia. Journal of the Royal Society of Western Australia 61: 1-10.

Richardson, N. (1992). Conjoin sets and stratigraphic integrity in a sandstone shelter: Kenniff Cave,
Queensland, Australia. Antiquity 66: 408-418.

Schwede, M.L. (1983). An archaeological survey for Aboriginal sites along gas pipeline laterals in the East Perth Metropolitan area. Unpublished report prepared for Dames and Moore, Environmental Consulting Engineers.

Schwede, M.L. (1984). A report on archaeological excavations on Bennett Brook Sites S1431 and S1940. Unpublished report prepared for Dames and Moore, Environmental Consulting Engineers.

Schwede, M.L. (1990). Quartz, the multifaceted stone: a regional prehistory of the Helena River Valley on the Swan Coastal Plain of Southwestern Australia. PhD Thesis, University of Western Australia: Nedlands.

Schiffer, M.B. (1983). Toward the identification of formation processes. American Antiquity 48: 675-706.

Schiffer, M.B. (1987). Formation processes of the archaeological record. University of New Mexico Press: Albuquerque.

Stockton, E.D. (1973). Shaw's Creek Shelter: human displacement of artefacts and its significance. Mankind 9: 112-127.

Tempus Archaeology (2006). Brookdale redevelopment - interim report on Phase 1: archaeological survey findings. Unpublished report prepared for the Armadale Redevelopment Authority: Armadale, Australia.

MANUSCRIPT RECEIVED JANUARY 2007; ACCEPTED NOVEMBER 2008. 